\title{
Collaborative Governance on Tourism Growth in the New Normal Era during the Covid-19 Pandemic in Indonesia
}

\author{
$1^{\text {st }}$ Mustiqowati Ummul Fithriyyah ${ }^{1}, 2^{\text {nd }}$ Agus Setio Widodo ${ }^{2}$ \\ \{mustiqowati@uin-suska.ac.id ${ }^{1}$,dosen_muda@yahoo.co.id ${ }^{2}$ \} \\ UIN Sultan Syarif Kasim Riau, 085226260380¹, Universitas Pancasila Tegal, 08156559044²
}

\begin{abstract}
This study aims to analyze and describe Collaborative Governance for Tourism Growth in the New Normal Era during the Covid-19 Pandemic in Indonesia. In conducting, a study on Collaborative Governance is through the literature study method was obtained from several research journals and data reported by the UN World Tourism Organization (UNWTO). Statistic Indonesia, and the Ministry of Tourism and Creative Economy relating to economic growth of a country, the Central Government, Regional Government (Provincial/City/Regency Government), and the private sector must have a strong synergy among the stakeholders involved in the tourism sector. It describes joint efforts as a type of problem-solving involving government and non-government agencies that pay attention to the case, especially in the field of tourism, which is currently experiencing a decline during the Covid-19 Pandemic. Practically, it is undeniable that the government becomes the determinant and policymaker with more possibilities to dominate and still require the participation of other stakeholders within today's society. The results of the study shows that the policies that can be taken and implemented by the Central Government through the Ministry of Tourism and Creative Economy and supported by the Government at the Provincial/Regency/City level. Through the Tourism Office and local tourism business entrepreneurs are by trying to prepare destinations, which are suitable with the post-Covid-19 "New Normal" conditions based on the principles of excellent hygiene and sanitation, offering a unique local experience, and good visitor management so that there is no overcrowding. In addition, tourism destinations are also encouraged to continue to improve and be more aggressive in applying the principles of sustainable tourism development (resilience, sustainable, and responsible).
\end{abstract}

Keywords: Collaborative Governance, Tourism, Covid-19 Pandemic, and New Normal Era

\section{Introduction}

National tourism is one of the industries affected by the corona outbreak. Changes in behavior and technology are the key to the survival of the tourism industry in this pandemic. Covid-19 is a global pandemic that has a devastating impact on humans and society. The epidemic spread from China and quickly spread to 210 countries including Indonesia. It has had a huge impact on the global economy including Indonesia. The economy has been in a downturn for at least the first half of this year, and if containment measures against the Covid19 outbreak are ineffective, it may last longer. The Covid-19 pandemic has disrupted global 
and domestic supply chains, financial market volatility, consumer demand shocks, and negative impacts on key industries such as travel and tourism.

The impact of the Covid-19 outbreak will be felt throughout the tourism value chain. It is expected that SMEs will be particularly affected. The number of foreign tourists has fallen sharply, with a large number of cancellations and a decline in bookings. The pressure on the tourism industry is particularly obvious. The decline is also due to the slowdown in domestic travel, especially because Indonesians are reluctant to travel because they are worried about the impact of Covid-19. It can be seen from the data of the Ministry of Tourism that compared with the same period last year, the number of tourists has decreased. As in Figure 1.1 below.

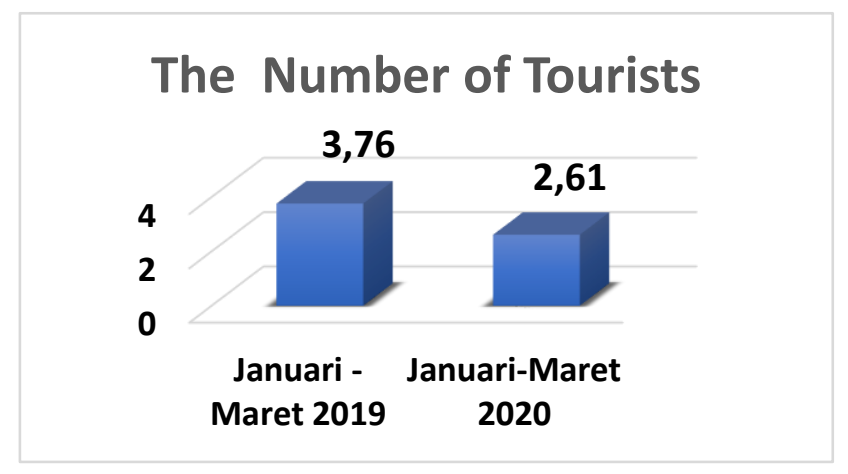

Source: Ministry of Tourism, 2020.

Fig. 1.1 Number of Tourist Declines in Indonesia.

Based on Figure 1.1, it can be seen that since the coronavirus outbreak broke out around the world, the number of foreign tourists visiting Indonesia has slowly decreased. Cumulatively from January to March, the number of tourists who came only reached 2.61 million people, or a drop of 30.62 percent; compared to the same period last year which was 3.76 million people. When compared to February, the number of tourist arrivals decreased 45.50 percent; meanwhile, if compared to the same period last year, the decline was recorded even more drastically, which is 64.11 percent. The loss from the tourism sector is predicted to reach IDR 60 trillion.

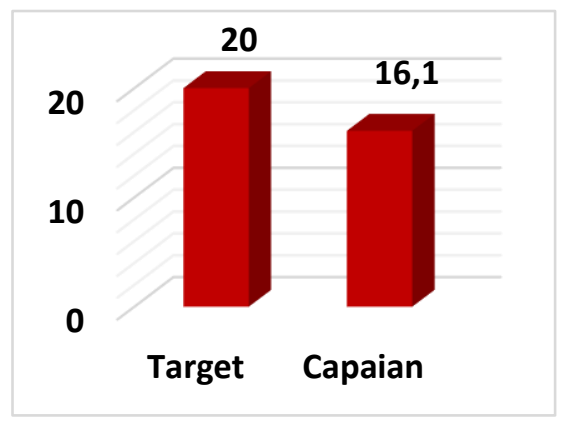

Source: Ministry of Tourism, 2020.

Fig. 1.2 Targets and Accomplishments Number of Indonesian Tourists in 2019. 
Based on Figure 1.2, it can be seen that the condition of tourism in Indonesia was not good enough before the Covid-19 pandemic in 2019. Data reported by the Ministry of Tourism showed that the targets and achievements in 2019 were far from expectations. The number of tourists targeted to visit Indonesia in 2019 was 20 million, but the results showed that at the end of the year there were only 16.1 million tourists who came to Indonesia. The unrealized of the expected targets and the decreasing number of tourists during the Covid-19 pandemic requires new policies from the government to re-grow the interest of tourists to come back to Indonesia.

\section{Literature Review}

Collaborative governance explained that managers and public representatives working in local government agencies, Therefore, governance is a way to manage a country's economy and provide social resources by regulating the relationship between the government and society to create policies to be implemented and evaluated so that there is a harmonious interaction between a government with other, society, and the private sector.

Table. 1 Teoritical Framwok

\begin{tabular}{|c|c|c|c|}
\hline $\begin{array}{c}\text { Teoritical } \\
\text { framework }\end{array}$ & Author & $\begin{array}{l}\text { Context Of } \\
\text { Research }\end{array}$ & Finding \\
\hline \multirow[t]{3}{*}{ Governance } & $\begin{array}{l}\text { Neo and Chen } \\
\text { (2007: 7); }\end{array}$ & $\begin{array}{l}\text { Relationship } \\
\text { between } \\
\text { government and } \\
\text { society }\end{array}$ & $\begin{array}{l}\text { Regulations, institutions, and } \\
\text { networks is really important } \\
\text { thing to maintain good } \\
\text { governance. }\end{array}$ \\
\hline & $\begin{array}{l}\text { Dwiyanto, } \\
\text { Noerhaeni (2010: } \\
\text { 25-26) }\end{array}$ & Governance system & $\begin{array}{l}\text { There are three-dimension; } \\
\text { social values, freedom, and } \\
\text { humanity. To get public } \\
\text { problems that exist in their } \\
\text { environment to solve. }\end{array}$ \\
\hline & $\begin{array}{l}\text { Sirker and Cosic, } \\
\text { 2007; Sullivan, } \\
2001\end{array}$ & Good governance & $\begin{array}{l}\text { Implementing the principle of } \\
\text { good governance effectively } \\
\text { ensures accountability, } \\
\text { transparency, and legitimacy. } \\
\text { Can give an impact on local } \\
\text { communities. }\end{array}$ \\
\hline \multirow[t]{2}{*}{$\begin{array}{c}\text { Collaborative } \\
\text { governance }\end{array}$} & $\begin{array}{l}\text { Jones et al., 2007; } \\
\text { Navarra and } \\
\text { Cornford, } 2005\end{array}$ & Public Service & $\begin{array}{l}\text { Collaborative governance } \\
\text { explained representatives } \\
\text { working in local government } \\
\text { need to consider approach to } \\
\text { service delivery to public. }\end{array}$ \\
\hline & $\begin{array}{l}\text { Kanat and Ozkan, } \\
\text { 2009; Hope, 2009; }\end{array}$ & $\begin{array}{l}\text { Public engagement } \\
\text { on Development }\end{array}$ & $\begin{array}{l}\text { Local people need to come } \\
\text { forward to share knowledge to }\end{array}$ \\
\hline
\end{tabular}




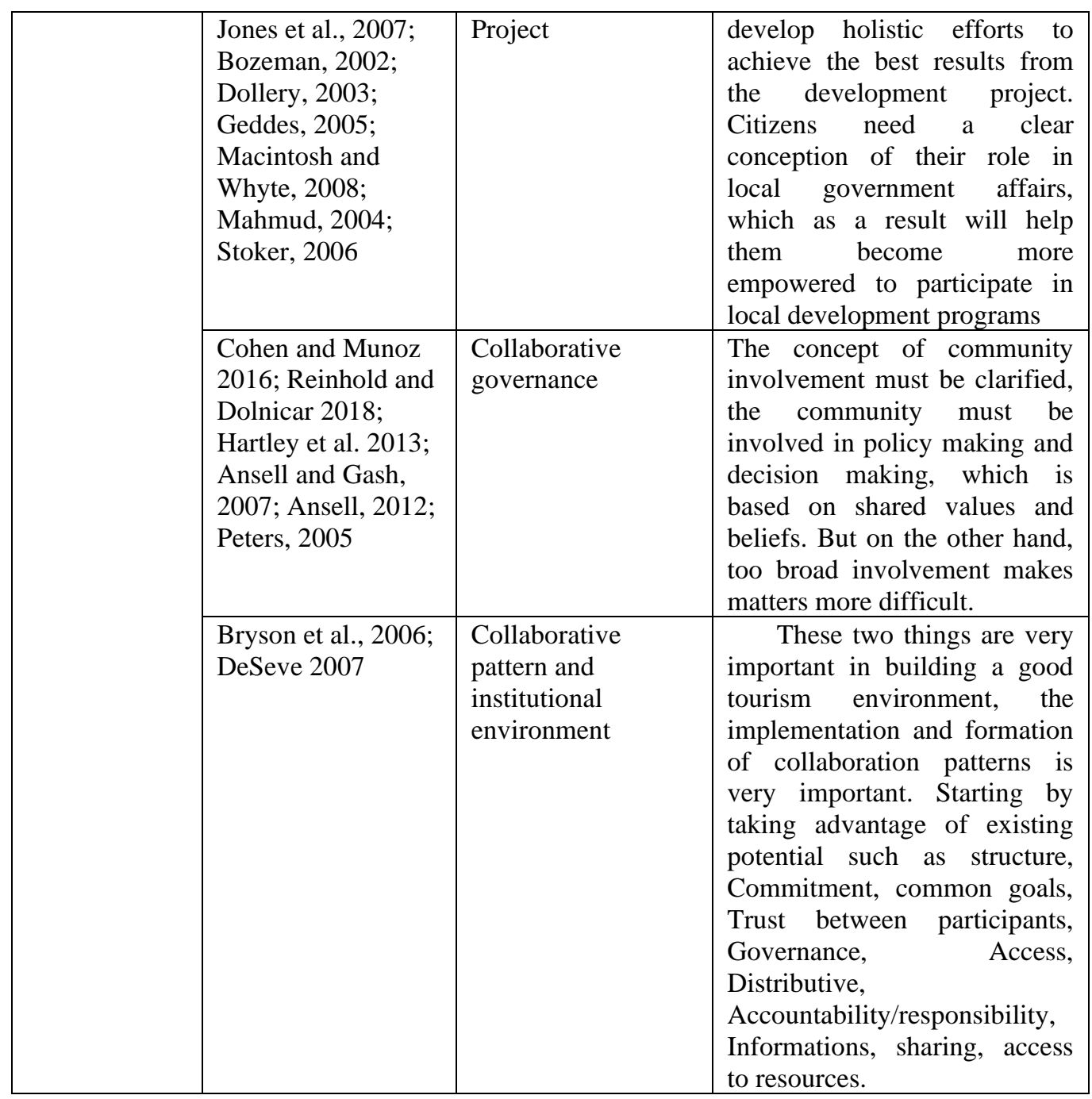

\section{Methodology}

The analysis of this study was carried out through a literature review related to the tourism Indonesia's Indonesia during the Covid-19 pandemic, the targets and achievements of tourists' visit in Indonesia, and the decreasing number of tourists in the same period of the year before the Covid-19 occurred. The literature review is conducted from various points of view; theory and journals to study determinants and risk factors related to tourism development policies that will be carried out by the government during the current New Normal era. The journal explore from internet that discuss about relating problem such as tourism development and tourism management in a country. The result of employment data 
analysis is one of the community-based information used in analyzing determinants related to tourism policy problems in Indonesia during the Covid-19 pandemic. Information about policies and programs is obtained from related sectors, including the World Tourism Organization (UNWTO) via internet access.

\section{Results and discussion}

\subsection{Tourism conditions at the global and Indonesian level}

The World Tourism Organization (UNWTO) released the news in March 2020 that the impact of Covid-19 will be felt in all tourism sectors in Indonesia. more than $80 \%$ of small and medium-sized businesses in the tourism sector were affected with tremendous losses, it didn't stop there, there were millions of livelihoods around the world affected by Covid-19. In response to this, UNWTO estimates the growth of international tourists from negative $1 \%$ to $3 \%$. This resulted in a decrease in revenue or an estimated loss of US\$30 billion to US\$50 billion. Prior to the Covid-19 outbreak, international tourists were expected to grow between $3 \%$ and $4 \%$. Asia and the Pacific will be the worst-affected regions, with a decline in arrivals estimated to be around $9 \%$ and $12 \%$. The estimated decline in tourism can be seen in Figure 4.1 below.

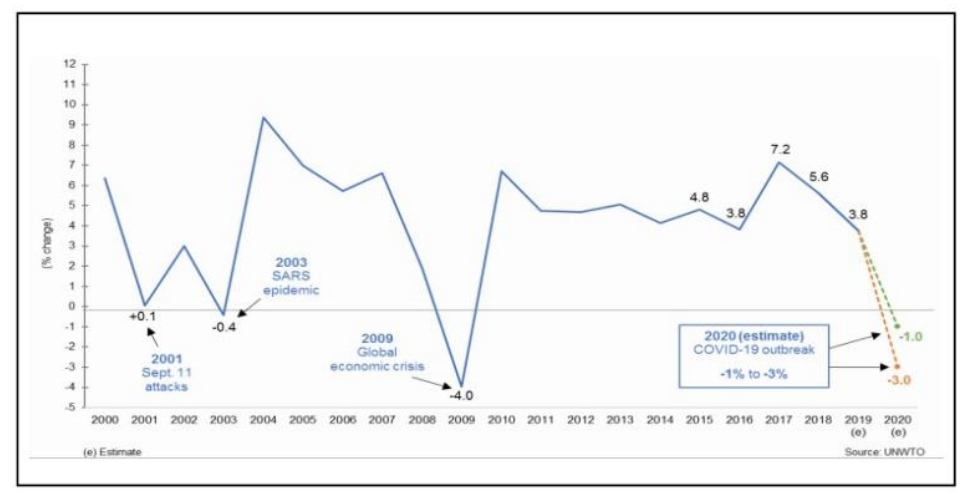

Source: UNWTO, 2020

Fig. 4.1 Estimated Decline in Tourism at the occurrence of Covid-19 in the world in 2020.

The tourism industry is faced with a major problem, namely a massive decline in the number of foreign tourist arrivals due to the territorial restrictions of various countries. The decline was also due to a slowdown in domestic travel, as some traffic flows also experienced a decline. mainly due to the reluctance of the Indonesian people to travel, due to their concerns about the impact of Covid-19. In addition, the decline in foreign tourist arrivals to Indonesia has also decreased when viewed from the number of foreign tourist arrivals entering through several international airports. When compared to December 2019, the number of foreign tourist arrivals at Indonesian airports in January 2020 decreased by 7.62 percent. 


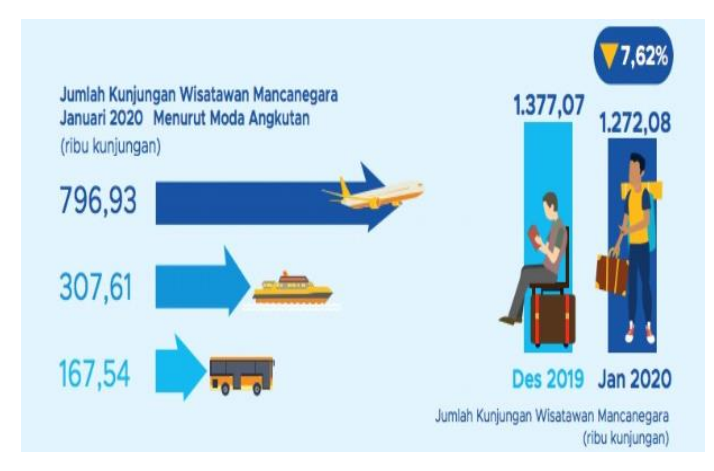

Source: BPS, 2020

Fig. 4.2 Number of Foreign Tourist Visits Based on the Mode of Transportation Used.

The decline in tourism and travel businesses has had a broad impact on SMEs, which in the end the workforce also disrupts job opportunities at an undetermined time. So far, tourism is a labor-intensive sector that absorbs more than 13 million workers in Indonesia. You can imagine if this sector experiences paralysis, how much material loss is experienced by the state, this does not include the multiplier effect that follows, including the creative industry, food industry and others, which are related below.

The decline in foreign tourists, especially to Indonesia, will affect foreign exchange earnings from tourism. Approximately, there are a 1.3 billion USD decrease in this sector. China is Indonesia's second-largest tourist source nation. Based on data from the National Labor Force Survey (Sakernas), the resources absorbed in tourism businesses continue to increase. It is from not only the number of workers but also the absorption of national labor in the tourism sector. This shows that tourism can be an alternative to reduce unemployment. In 2017 , the number of workers in the tourism industry reached 12.74 million people or 10.53 percent of the total national workforce of 121.02 million people.

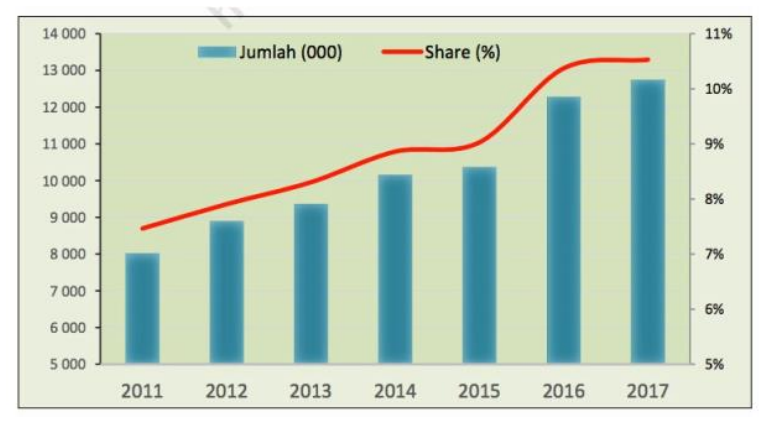

Source: BPS, 2018.

Fig. 4.3 Number of Workers in the Tourism Business, 2011-2017

Covid-19 impact in almost all sector of life including the tourism sector due to the travel restrictions, the cancellation of major events, and the reluctance to travel internationally and domestically. To overcome this storm, various countries are struggling to overcome the impact of the Covid-19 outbreak. 
In this difficult situation, there must be a breakthrough so that the tourism sector can bounce back. This sector must move and be productive again to improve the economy, the creative industry during the pandemic has not fully improved. Therefore, President Joko Widodo encourages the tourism sector to remain productive in these difficult times and those who are still surviving must and need to be appreciated. In a limited state and cabinet meeting, the President asked the tourism industry to be able to adapt to new habits and prepare a new normal concept for tourists. many parties agree with the President's direction because in order to survive, the tourism industry must adapt to the pandemic conditions. because the pandemic situation in the new normal era requires all tourist visitors to carry out health protocols, besides that the existing service model in the tourism sector must also adapt to the existing health protocols in Indonesia. New standards and new habits in the field of tourism really must be considered and developed so that tourism products can be adapted to the new era. so that visitors still enjoy traveling and the pandemic does not spread widely. In addition, there are several alternative tours that are predicted to be in demand in the new normal era, such as Solo travel tours, wellness tours, virtual tours, and satiations.

According to the President's direction, tourism products in the new normal era need to pay more attention to health, hygiene, safety, and security issues. We also believe that in Indonesia tourism products that are more creative can be created by our tourism industry, of course with its own comparative and competitive advantages. In addition, health protocols should not be left behind in existing services. The habit of keeping a distance, avoiding crowds, always wearing a mask, diligently washing hands must be part of a tourism product. We support the efforts of the Ministry of Tourism to develop these principles and protocols as a new standard for the tourism industry. With this new standard, it is hoped that creative guidelines will be created. This is also reinforced by the high will and maximum effort made by individuals in the tourism industry who believe that tourism will survive and be sustainable in the current new normal era in Indonesia.

In intervening the new normal policy in the tourism sector, the role of the government is very important. For example, several previous studies have revealed that collaboration is the key word in conducting policy interventions such as between stakeholders carried out by the government in the tourism sector, which can increase economic growth in the national income sector, and provide solutions to employment problems. there are many studies that also reveal about the tourism sector and its relation to the process of economic development in the world.

\begin{tabular}{|c|c|c|}
\hline Author & Context Of Research & Finding \\
\hline $\begin{array}{l}\text { Matijová et. Al. } \\
(2019)\end{array}$ & $\begin{array}{l}\text { Collaborative } \\
\text { governance } \\
\text { tourism sector }\end{array}$ & $\begin{array}{l}\text { the role of government and management in } \\
\text { policy interventions regarding the tourism } \\
\text { sector is urgently needed, and has } \\
\text { tremendous influence. }\end{array}$ \\
\hline $\begin{array}{l}\text { Mura and Kajzar } \\
(2019)\end{array}$ & $\begin{array}{l}\text { Stories of art culture } \\
\text { and history in torism }\end{array}$ & $\begin{array}{l}\text { one effective way to attract tourists can be } \\
\text { by selling stories and culture, as in the } \\
\text { Czech Republic, and so far it is considered } \\
\text { very effective }\end{array}$ \\
\hline $\begin{array}{l}\text { Ayini et. Al. (2020); } \\
\text { Qian et.al. (2018); } \\
\text { Cozma and Coros } \\
(2017)\end{array}$ & Sustainable tourism & $\begin{array}{l}\text { Sustainable tourism can be an option to } \\
\text { increase the regional economy seperti di } \\
\text { Romania. however, tourism supporting } \\
\text { sectors must also be good, such as the } \\
\text { creative industry, food and lodging, and }\end{array}$ \\
\hline
\end{tabular}




\begin{tabular}{|l|l|l|}
\hline $\begin{array}{l}\text { Tabash (2017); } \\
\text { Bunghez (2017); } \\
\begin{array}{l}\text { Mansour and Mahin } \\
\text { (2013) }\end{array}\end{array}$ & Ecomic and tourism & $\begin{array}{l}\text { supported by adequate infrastructure. } \\
\text { tourism revenues can contribute to } \\
\text { development. tourism also contributes to } \\
\text { the development of a region or country. }\end{array}$ \\
\hline Gaki et. al. (2016) & Tourism behavior & $\begin{array}{l}\text { tourists have different habits, so that in } \\
\text { traveling the level of satisfaction in visiting } \\
\text { tours becomes their main factor in deciding } \\
\text { and recommending tours to others. as } \\
\text { happened at Lonian in Greece. }\end{array}$ \\
\hline
\end{tabular}

\subsection{Direction of government policy in the tourism sector}

The trend of world tourism shows very rapid development each year. This is due to changes in the socio-economic structure of countries in the world and the increasing amount of people who have higher incomes. In addition, tourism has developed into a global phenomenon, a necessity, and a part of human rights that must be respected and protected. The central and regional governments, the tourism business world, and the community are obliged to ensure that tourism, as everyone's right, can be implemented to support human dignity and human enhancement, increased welfare, and friendship between nations in order to realize world peace.

In facing global change and strengthening people's rights to enjoy leisure time by traveling, it is necessary to develop tourism that is based on the diversity, uniqueness, and characteristic of the nation. In addition, tourism development must continue to pay attention to the population. The total population will be one of the main things in the development of tourism in the present and future because of its dual function, which are being a human resource asset and a potential source of domestic tourists.

Thus, tourism development can be used as a means to create awareness of national identity and togetherness in diversity. Tourism is developed with a growth and economic equality approach for people's welfare and oriented on regional development, communitybased, and community empowerment which includes various aspects, such as human resources, marketing, destinations, science and technology, cross-sector linkage, cooperation between countries, empowerment of small businesses, and responsibility in utilizing natural and cultural resources. It has been regulated in Law No.10 of 2009 on Tourism.

The government's role in developing tourism, in general, is to provide infrastructure (not only in physical form), expand various forms of facilities, coordinate activities between government officials and the private sector, regulate and promote it to other regions and abroad. The government has the authority in regulating, providing, and allocating various infrastructure related to tourism needs. Moreover, the government is responsible for determining the direction in which tourism travel is headed. The macro policies pursued by the government are a guide for other stakeholders in playing their respective roles.

Based on the strength, important position, and influence of stakeholders on an issue, stakeholders can be categorized into several groups. ODA (1995) categorized stakeholders into primary, secondary, and key stakeholders. As an illustration, the grouping of various government (public) policies, programs and projects can be presented.

Stakeholders also have several categories, namely: 
a. Primary stakeholders: are stakeholders who have a direct interest in a policy, program, and project, namely the community and community leaders as well as public managers.

b. Secondary stakeholders: does not have a direct interest in a policy, program, and project. However, they have concern and apprehension, namely government agencies, NGOs, universities, entrepreneurs (business entities).

c. Key Stakeholders: have the legal authority in terms of decision making which is an element of the executive according to their level, legislative, and agency. The subjects are the district government, the district parliament, the office that is directly in charge of the project concerned.

According to Law Number 10 of 2009 concerning Tourism, the respective authorities of the Central, Provincial to Regency/City Government and Entrepreneurs engaged in the Private Sector are as follows:

a. The central government has the authority to: compile and determine a master plan for national tourism development; coordinate the development of cross-sector and crossprovincial tourism; carry out international cooperation in the tourism sector in accordance with statutory provisions; determine the national tourist attraction; determine national tourism destinations; establish norms, standards, guidelines, procedures, criteria, and supervision system in the administration of tourism; develop policies for human resource development in the tourism sector; maintain, develop, and preserve national assets that become tourist attractions and untapped potential assets; conduct and facilitate the promotion of national tourism; provide facilities that support tourist visits; provide information and/or early warning related to security and safety of tourists; increase community empowerment and tourism potential owned by the community; supervise, monitor, and evaluate the tourism administration; and allocate a tourism budget.

b. Provincial Government: prepare and determine the provincial tourism development master plan; coordinate the implementation of tourism in its territory; carry out a registration, recording, and data collection of tourism business registration; determine provincial tourism destinations; determine provincial tourist attraction; facilitate the promotion of tourism destinations and tourism products in their territory; maintain provincial assets that become provincial tourist attractions; and allocate a tourism budget.

c. The regency/city government has the authority to prepare and stipulate a master plan for regency/city tourism development; determine regency/city tourism destinations; determine regency/city tourist attractions; carry out registration, recording, and data collection of tourism business registration; regulate the operation and management of tourism in its territory; facilitate and promote tourism destinations and tourism products in their territory; facilitate the development of new tourist attractions; conduct tourism training and research within the regency/city scope; maintain and preserve tourist attractions in the region; organize tourism awareness community guidance; allocate a tourism budget, and

d. Every tourism entrepreneur has the obligation to: maintain and respect the religious norms, customs, culture, and values that exist in the local community; provide accurate and responsible information; provide services that are not discriminatory; provide comfort, friendliness, security protection and safety of the tourists; provide insurance protection for tourism businesses with high-risk activities; develop partnerships with micro, small, and local cooperatives that are in need, strengthen and benefit each other; prioritize the use of local community products, domestic products, and provide opportunities for local workers; improve workforce competence through training and education; play an active role in developing infrastructure and community empowerment 
programs; participate in preventing all forms of actions that violate decency and activities that violate the law in the environment where the business is carried out; maintain a healthy, clean, and beautiful environment; maintain the preservation of the natural and cultural environment; maintain a good image of Indonesia through responsible tourism business activities; and apply business standards and competency standards in accordance with the provisions of laws and regulations.

\section{Conclusion}

The Central Government from level, up to the Department of Tourism at the Provincial and Regency/City levels as well as entrepreneurs who are active in the field of tourism. They are trying to prepare destinations that are by post-Covid-19 "new normal" conditions according to the principles of good hygiene and sanitization, offering a unique local experience, and good visitor management so there will be no overcrowding. In addition, tourism destinations are also encouraged to continue to improve and be more aggressive in applying the principles of sustainable tourism development (resilience, sustainable, and responsible).

The principle of Collaborative Governance, in implementing sustainable tourism policies, can be understood as tourism that takes full account of the current and future economic, social and environmental impacts, meeting the needs of visitors, industry, the environment and local communities. Management practices and guidelines for sustainable tourism development can be applied to all forms of tourism activities in all types of tourist destinations, including mass tourism and various other types of tourism activities. The principle of sustainability refers to the environmental, economic, and socio-cultural aspects of a tourist destination.

Sustainable tourism development requires the participation of relevant stakeholders as well as strong political leadership to ensure active participation and agreement among stakeholders. Achieving sustainable tourism is a continuous process and requires continuous monitoring and innovation regarding the necessary preventive and corrective measures for the impact of tourism activities so that tourists feel safe and comfortable traveling in the current new normal era. 


\section{References}

[1] Ansell, C. and A. Gash. Collaborative Governance in Theory and Practice. Journal of Public Administration Research and Theory. 2007;

[2] Ansell, C. (2012) 'Collaborative Governance', in D. Levi-Faur (ed.), Oxford Handbook of Governance, Oxford and New York: Oxford University Press.

[3] Bozeman, B. (2002), "Public-value failure: when efficient markets may not do", Public Administration Review, Vol. 62 No. 2, pp. 145-61

[4] Bryson, J.M., B.C. Crosby, and M.M. Stone (2006) 'The Design and Implementation of CrossSector Collaborations: Propositions from the Literature', Public Administration Review.

[5] Cozma and Coroz. (2017). TOURISM DEVELOPMENT IN RODNA MOUNTAINS NATIONAL PARK: THE PUBLIC ADMINISTRATION, A KEY STAKEHOLDER. Journal of Tourism Studies and Research in Tourism · December 2017.

[6] Corina Larisa Bunghez (2016), "The Importance of Tourism to a Destination's Economy", Journal of Eastern Europe Research in Business \& Economics, Vol. 2016 (2016), Article ID 143495, DOI: $10.5171 / 2016.143495$.

[7] Dollery, B. (2003), "A critical evaluation of virtual local government in Australia", Australian Journal of Public Administration, Vol. 62 No. 3, pp. 82-91.

[8] Deseve, Edward. 2007. Creating public value using managed networks. In R.S. Morse, T.F. Buss, C. M. Kinghorn. Transforming public leadership for the $21^{\text {st }}$ century. Armonk, NY: M.E. Sharpe.

[9] Eleni Gaki et. al. The Evaluation of Tourist Satisfaction in Island Destinations: The Case of the Ionian Islands, Greece. 56th Congress of the European Regional Science Association: "Cities \& Regions: Smart, Sustainable, Inclusive?", 23-26 August 2016, Vienna, Austria Provided in Cooperation with: European Regional Science Association (ERSA).

[10] Folorunso C. O., Ayeni Dorcas A. Ayeni T. O. (2020). Impact of Tourism Oriented Architectural Features on Sales in Shopping Malls of Metropolitan Lagos, Nigeria. American Journal of Tourism Management 2020, 9(1): 19-23

[11] Geddes, M. (2005), "International perspectives and policy issues", in Smyth, P., Reddel, T. and Jones, A. (Eds), Community and Local Governance in Australia, University of New South Wales Press, Sydney, pp. 13-34

[12] Hartley, J., E. S.rensen and J. Torfing (2013) 'Collaborative Innovation: A Viable Alternative to Market Competition and Organizational Entrepreneurship', Public Administration Review , 73(6), 821-32

[13] Hope, K.R. Sr (2009), "Capacity development for good governance in developing countries: some lessons from the field", International Journal of Public Administration, Vol. 32 No. 8, pp. 728-40. Palgrave

[14] Jianwei Qian , Huawen Shen and Rob Law. (2018). Research in Sustainable Tourism: A Longitudinal Study of Articles between 2008 and 2017. Sustainability 2018, 10, 590; doi:10.3390/su10030590.

[15] Jones, S., Hackney, R. and Irani, Z. (2007), "Towards e-government transformation: conceptualising 'citizen engagement': a research note", Transforming Government: People, Process and Policy, Vol. 1 No. 2, pp. 145-52.

[16] Kanat, I.E. and Ozkan, S. (2009), "Exploring citizens' perception of government to citizen services: a model based on theory of planned behaviour (TPB)", Transforming

[17] Ladislav Mura, Patrik Kajzar. (2019). Small Businesses in Cultural Tourism in a Central European Country. Journal Tourism and Service. Vol. 10, No.19.

[18] Luis Seguí-Amortegui, José Antonio Clemente-Almendros, Rubí Medina and Melanie Grueso Gala. (2019). Sustainability and Competitiveness in the Tourism Industry and Tourist Destinations: A Bibliometric Study. Sustainability 2019, 11, 6351; doi:10.3390/su11226351.

[19] Macintosh, A. and Whyte, A. (2008), "Towards an evaluation framework for eparticipation", Transforming Government: People, Process and Policy, Vol. 2 No. 1, pp. 16-30.

[20] Mahmud, S. (2004), "Citizen participation in the health sector in rural Bangladesh: perceptions and reality", IDS Bulletin, Vol. 35 No. 2, pp. 11-18 
[21] Muñoz, P. and Cohen, B. (2017) Mapping out the sharing economy: A configurational approach to sharing business modeling, Technological Forecasting and Social Change, DOI: 10.1016/j.techfore.2017.03.035.

[22] Mansour Esmaeil Zaei, Mahin Esmaeil Zaei. (2013). THE IMPACTS OF TOURISM INDUSTRY ON HOSTCOMMUNITY. European Journal of Tourism Hospitality and Research. Vol.1, No.2, pp.12-21, September 2013

[23] Mosab I. Tabash. (2017). The Role of Tourism Sector in Economic Growth: An Empirical Evidence From Palestine. International Journal of Economics and Financial Issues 7(2), 103-108.

[24] Mária Matijová, Erika Onuferová, Martin Rigelský, Vladislav Stanko. (2019). Impact of Selected Indicators of Tourism Capacity and Performance in the Context of the Unemployment Rate in Slovakia. Journal Tourism and Service. Vol. 10, No.19.

[25] Neo, Boon Siong dan Geraldine Chen. 2007. Dynamic Governance Embedding Culture, capabilities and Change in Singapore. Danvers: World Scientific Publishing Co., Pte.,Ltd

[26] Navarra, D.D. and Cornford, T. (2005), "ICT, innovation and public management: governance, models \& alternatives for egovernment infrastructures", paper presented at the 13th European Conference of Information Systems, Regensburg, May 26-28.

[27] Peters, B.G. (2005) 'The Problem of Policy Problems', Journal of Comparative Policy Analysis: Research and Practice, 7(4), 349- 70.

[28] Reinhold, Stephan dan Sara Dolnicar.2018. The Sharing Economy. Goodfellow Publishers Limited: Oxford

[29] Sirker, K. and Cosic, S. (2007), Empowering the Marginalized: Case Studies of Social Accountability Initiatives in Asia, World Bank Institute, Washington, DC.

[30] Sullivan, H. (2001), "Modernisation, democratisation and community governance", Local Government Studies, Vol. 27 No. 3, pp. 1-24

[31] Stoker, G. (2006), "Public value management: a new narrative for networked governance?", American Review of Public Administration, Vol. 36 No. 1, pp. 41-57 